\title{
FERTILITY IN LILIUM HYBRIDS
}

\author{
R. D. BROCK
}

John Innes Horticultural Institution, Hertford, Herts. and Commonwealth Scientific and Industrial Research Organisation, Canberra, Australia

\section{INTRODUCTION}

Received 26.x.53

Fertility, as measured by seed setting after self or cross pollination, depends on pollen fertility, embryo-sac fertility, success of fertilisation and normality of embryo and endosperm development. Fertility can be reduced by abnormalities in any of these stages and in structural hybrids both genotypic and segregational sterility operates. Segregation in structural hybrids leads to both genic and numerical unbalance

TABLE I

Percentage of Lilium hybrids

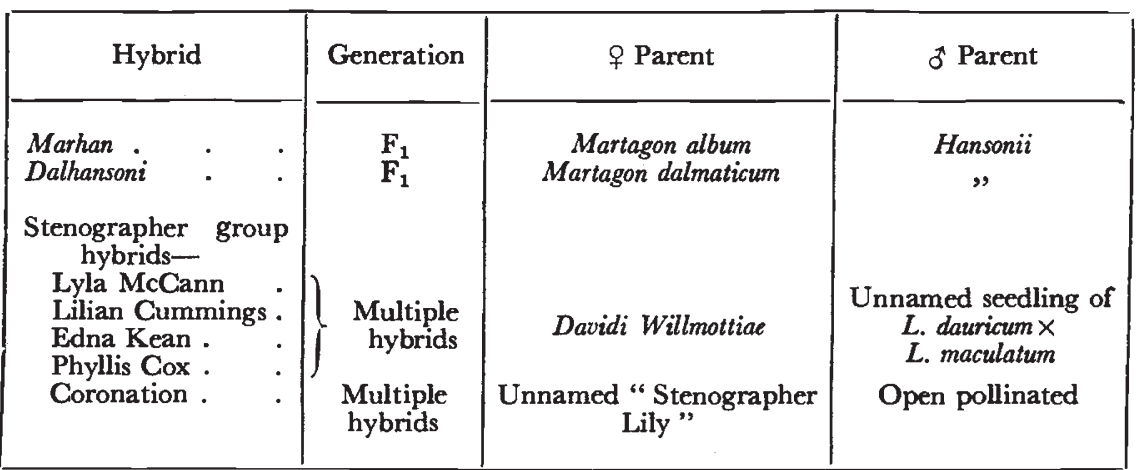

in the gametes. Unbalanced gametes cannot survive and fertility is reduced. Individually viable gametes can produce unbalanced combinations, resulting in sterility in the zygote.

The development of squash techniques allows us to examine the male and female gametes and also the developing seeds. It offers us an opportunity of re-examining the abnormalities reducing fertility in structural hybrids.

\section{MATERIALS AND METHODS}

Two $F_{1}$ hybrids, Marhan and Dalhansoni, and several multiple hybrids were used in these studies. Parentages are given in table I (Woodcock and Stearn, 1950). A number of species including both self-fertile and self-sterile forms were used throughout as controls.

Meiosis in pollen mother cells (PMC) was studied in smears stained with Feulgen reagent (hydrolysis $\mathrm{N} / \mathrm{r} \mathrm{HCl}, 60^{\circ} \mathrm{C} ., 6$ mins.) or aceto-carmine squashes made after fixation in methyl alcohol or acetic alcohol $(\mathbf{r}: 3)$.

Embryo-sacs and endosperms were dissected and squashed in 45 per cent. acetic acid after fixation in Carnoy fluid $(6: 3: 1)$ and staining with Feulgen reagent (hydrolysis ro mins.). 
Pollen tube growth in styles and pollen fertility were measured after staining with 0.4 per cent. cotton blue in lacto-phenol.

For fertilisation studies ovules were embedded in wax, sections cut $40 \mu$ thick and stained with crystal violet.

\section{DEVELOPMENT OF POLLEN}

Meiosis in pollen mother cells.-The species had high chiasma frequencies and complete pairing at MI. The hybrids had reduced chiasma frequency (table 2) which resulted in univalent formation (fig. I).

TABLE 2

Metaphase pairing and chiasma frequency in PMC of Lilium species and hybrids ( 12 cells in each)

\begin{tabular}{|c|c|c|c|c|c|c|c|c|}
\hline & \multirow{2}{*}{ Cells } & \multicolumn{4}{|c|}{ Metaphase pairing } & \multirow{2}{*}{ I per cell } & \multicolumn{2}{|c|}{$\begin{array}{l}\text { Chiasma } \\
\text { frequency }\end{array}$} \\
\hline & & $12^{11}$ & ${ }^{11} I^{I I}$ & $10^{\mathrm{II}}$ & $9^{\mathrm{II}}$ & & $\begin{array}{l}\text { Total } \\
\text { Xta }\end{array}$ & $\begin{array}{c}\text { Xta p. } \\
\text { pot. } \\
\text { biv. }\end{array}$ \\
\hline \multicolumn{9}{|l|}{ SPECIES } \\
\hline L. candidum & 50 & 49 & I & $\ldots$ & $\ldots$ & 0.02 & 453 & $3 \cdot 15$ \\
\hline L. Davidi & 50 & 50 & $\ldots$ & $\ldots$ & $\ldots$ & $\ldots$ & 478 & $3 \cdot 32$ \\
\hline L. Hansonii . & $5^{\circ}$ & 50 & $\ldots$ & $\ldots$ & $\ldots$ & $\ldots$ & 480 & $3 \cdot 33$ \\
\hline L. Henryi & 50 & 50 & $\ldots$ & $\ldots$ & $\ldots$ & $\ldots$ & 496 & 3.44 \\
\hline L. pardalinum & 50 & 50 & $\cdots$ & $\ldots$ & $\cdots$ & $\ldots$ & 530 & $3 \cdot 68$ \\
\hline L. regale . & 50 & 50 & $\cdots$ & $\ldots$ & & & $55^{6}$ & $3 \cdot 86$ \\
\hline \multicolumn{9}{|l|}{ First CROsses } \\
\hline Marhan & 50 & 33 & 16 & I & $\ldots$ & 0.72 & $3^{82}$ & 2.56 \\
\hline Dalhansoni . & 50 & 43 & 7 & $\ldots$ & $\cdots$ & 0.28 & 401 & $2 \cdot 78$ \\
\hline \multicolumn{9}{|l|}{ MULTIPLE HYBRIDS } \\
\hline Lyla McCann & 50 & 25 & 24 & $\ldots$ & I & $\mathrm{r} \cdot 08$ & 299 & $2 \cdot 0 I$ \\
\hline Lilian Cummings & 50 & 40 & 9 & I & $\ldots$ & 0.44 & 361 & $2 \cdot 5 I$ \\
\hline Edna Kean . & 50 & 36 & 14 & $\cdots$ & $\cdots$ & $0 \cdot 56$ & $3^{83}$ & $2 \cdot 66$ \\
\hline Phyllis Cox. & 50 & 46 & 4 & $\ldots$ & $\ldots$ & 0.16 & 433 & $3 \cdot 01$ \\
\hline Coronation & 50 & 29 & 17 & 3 & I & I.04 & 384 & $2 \cdot 67$ \\
\hline
\end{tabular}

Crossing-over in inverted segments in structural hybrids results in bridges and fragments at first or second anaphase (Richardson, 1936). The inversion crossing-over frequency is a measure of hybridity with respect to inverted segments, but the reduced chiasma frequency in the hybrids tends to mask the full expression of these changes. A more accurate estimate of the hybridity is given by the coefficient of hybridity which compensates for the reduced crossing-over in the inverted segments (table 3 ).

Plotting the chiasma frequency against the inversion crossing-over frequency or the coefficient of hybridity (fig. 2) clearly indicates the different orders of structural hybridity in the different hybrids. The "stenographer group" hybrids all have a similar level of structural 
hybridity. The $\mathrm{F}_{1}$, Marhan, resulting from different parents, has much increased hybridity. The open pollinated derivative from the "stenographer group", Coronation, is clearly not a result of selfing within the group for its hybridity is increased. This is borne out by the unusual flower colour of this plant, yellow with purplish-maroon spots, compared with the orange-red flowers of the stenographer group hybrids.

A further indication of structural hybridity is the segregation for a factor or factors controlling the rate of cell division. This is observed as failure of synchronisation of sister cells at second division of meiosis (table 3). This characteristic may be useful in detecting hybrids

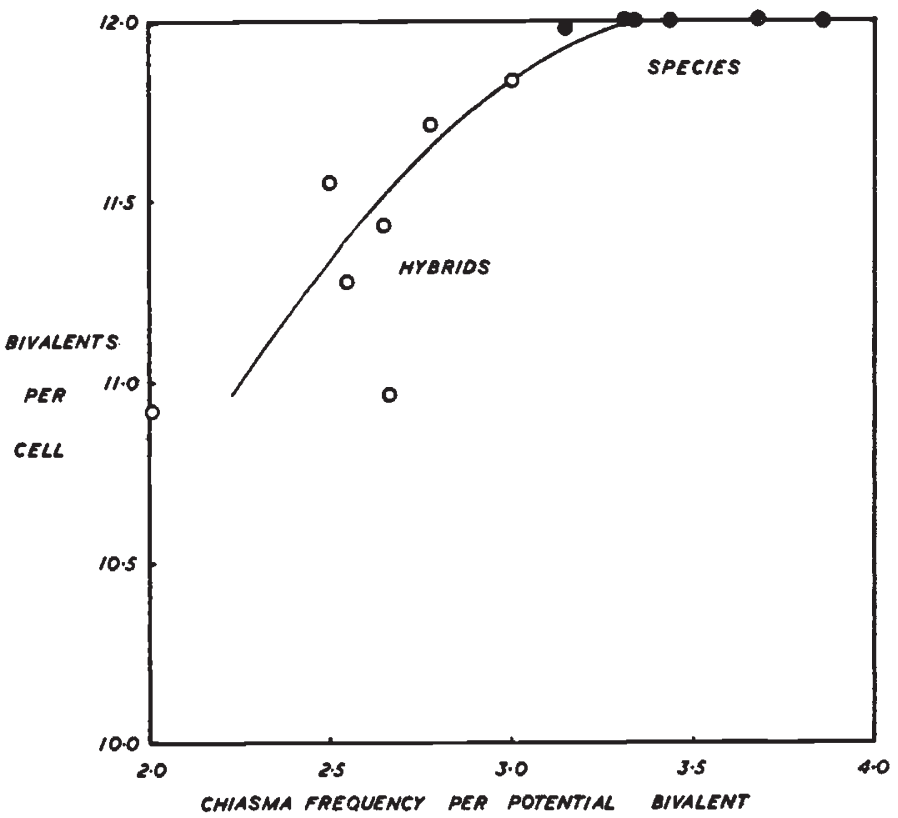

FIG. I.-Relation between chiasma frequency per potential bivalent and metaphase pairing in PMC of Lilium species (closed circles) and hybrids (open circles).

where inversion crossing-over is absent or very rare. A further abnormality which reduces pollen fertility is spontaneous chromosome breakage in PMC. This was to be inferred in two ways :-(i) in L. candidum and Lilian Cummings fragments occurred at M I and M II accompanied by greatly reduced chiasma frequency at MI. (ii) In several of the hybrids there was occasionally sister reunion of unbroken ends. This gives rise to anaphase bridges without accompanying fragments. Mechanical breakage of the bridges results in chromosome breakage.

Loss of lagging univalents and breaking of anaphase bridges after inversion crossing-over will result in pollen grains deficient for chromosomes or parts of chromosomes. Such deficient nuclei, except in rare cases such as in Hyacinthus (Brock, unp.) are expected to be inviable. Do they in fact reduce pollen fertility? 
Pollen fertility.-Considering the species and the hybrids $\mathrm{I}$ find a relationship between the chiasma frequency and the pollen fertility (fig. 3). In the hybrids pollen fertility is more closely related to the univalents per cell plus the inversion crossing-over frequency per cell (fig. 4) for this takes into account the loss due to inversions as well as that due to lagging univalents.

Thus segregation is the main factor reducing pollen fertility. The reduction in fertility was in no case complete (table 7). As a large

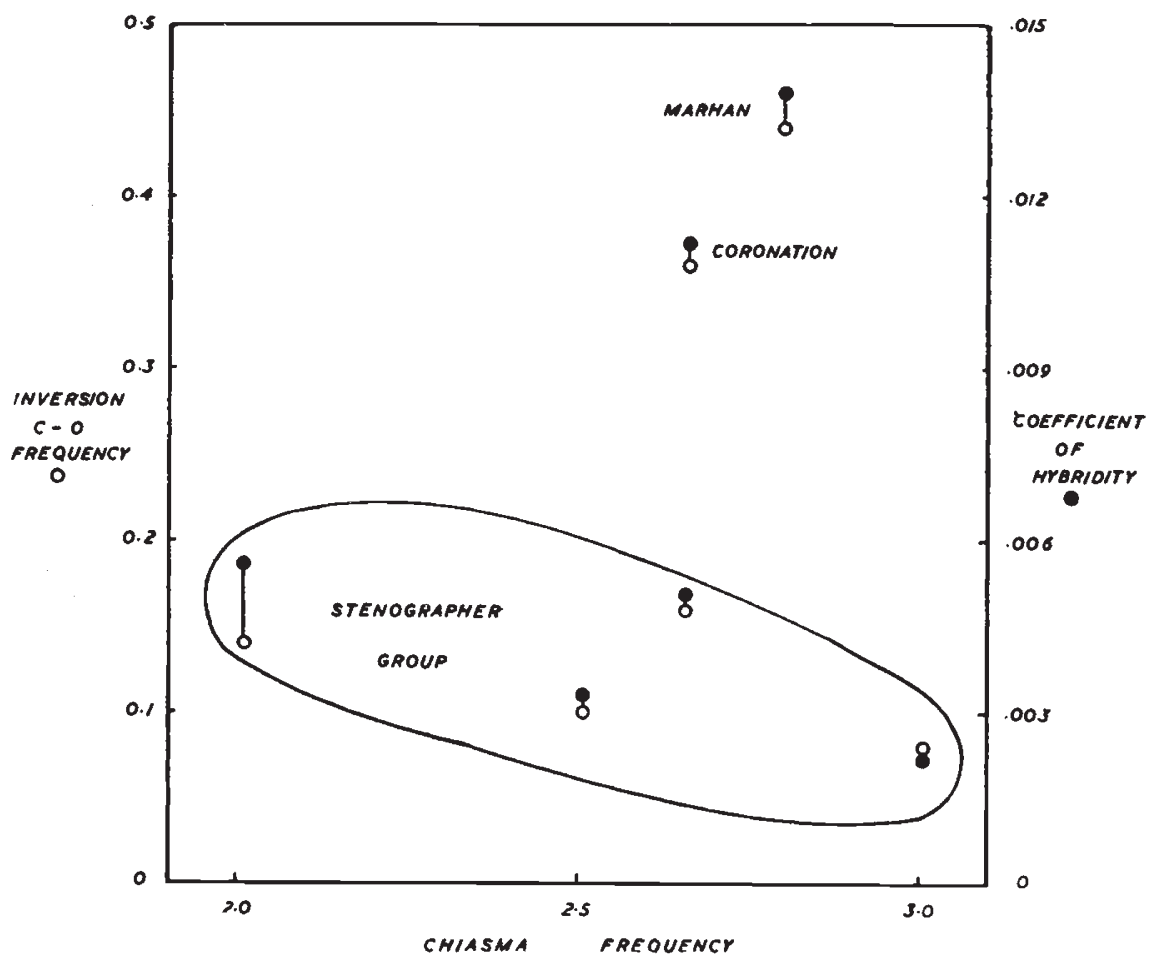

FIG. 2.-Chiasma frequency per potential bivalent plotted against inversion crossing-over frequency and coefficient of hybridity in PMC of Lilium hybrids.

surplus of pollen is produced this pollen sterility probably has little direct effect on the overall fertility of the plants.

\section{EMBRYO-SAC DEVELOPMENT}

Normal development.-The normal development of the embryo-sac in Lilium is illustrated in fig. 5 and plate I. Mitoses are synchronised and no cell walls are formed until the embryo-sac is fully developed. After meiosis one of the haploid nuclei migrates from the micropylar end to the chalazal end of the embryo-sac. At the next mitosis the remaining micropylar nucleus divides, at the same time the three chalazal nuclei form a common spindle and produce two triploid nuclei. One more mitosis produces four haploid and four triploid nuclei. The haploid nuclei form the egg, two synergids and one 
TABLE 3

Inversion crossing-over frequency, coefficient of hybridity in regard to inversions and synchronisation of sister cells at second division in PMC of Lilium species and hybrids

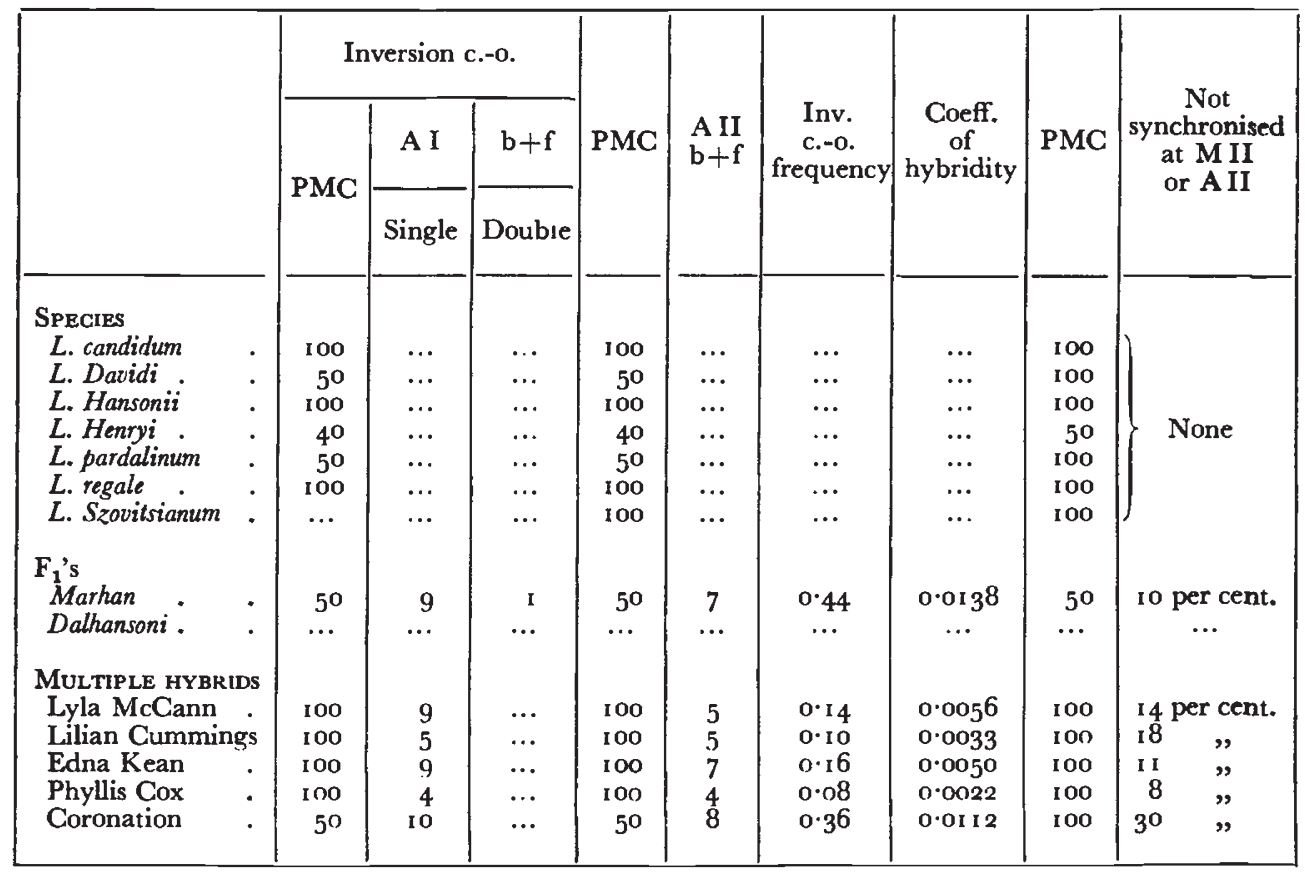

Note.-Inversion crossing-over frequency calculated by adding together the frequency of bridges at first and second division per mother cell, counting double first division bridges as six (Darlington, I937, p. 271).

Coefficient of hybridity in regard to inversion calculated by dividing inversion crossing-over frequency by chiasma frequency per cell.

TABLE 4

Metaphase pairing and chiasma frequency in embryo-sacs of Lilium species and hybrids

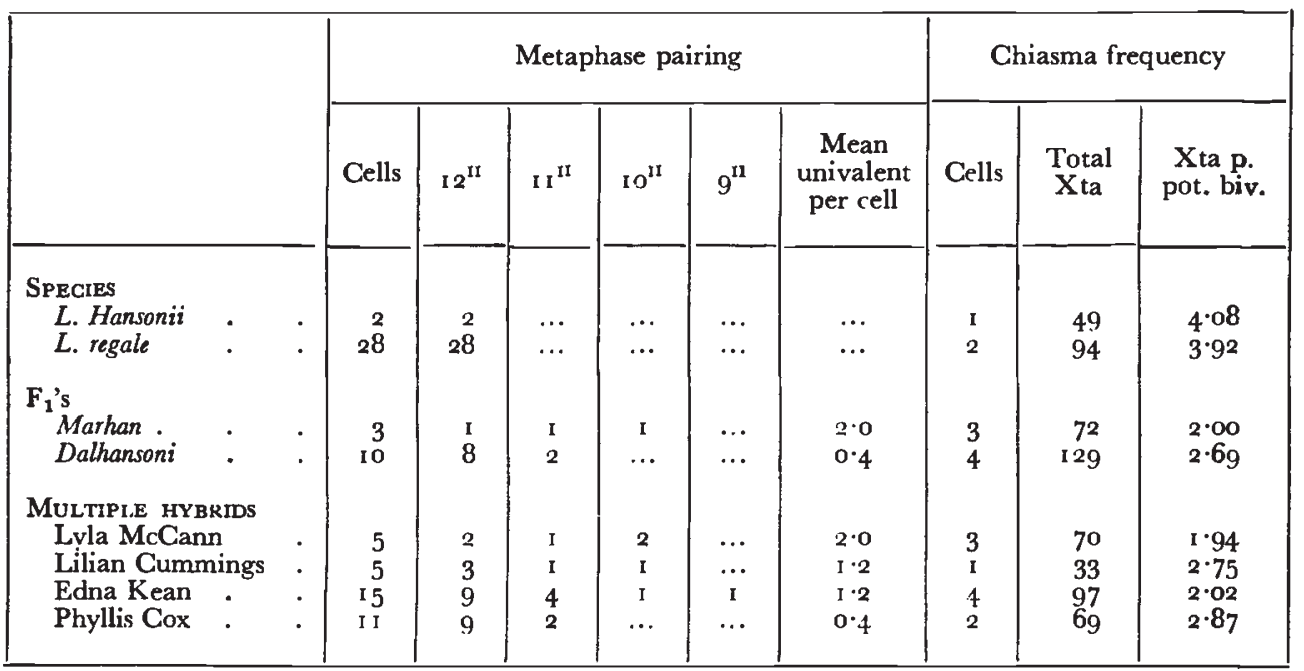

Nolo. - Two cells of $L$. candidum and 5 cells of $L$. pardalinum each had 12 II's. 
polar' nucleus. The triploid nuclei form the other polar nucleus and the antipodals.

Abnormalities occurred frequently in hybrids and rarely in the species. Some of the abnormalities are illustrated in plate 2. They are of two kinds, chromosomal abnormalities and errors of synchronisation or differentiation.

Chromosome abnormalities.-The chiasma frequency in the embryosac mother cells was similar to that in the PMC's (fig. 6) as was also

TABLE 5

Abnormal chromosome distribution in individual embryo-sacs of Lilium species and hybrids

\begin{tabular}{|c|c|c|c|}
\hline Stage & $\begin{array}{l}\text { Hybrid or } \\
\text { species }\end{array}$ & $\begin{array}{l}\text { Chromosome } \\
\text { distribution }\end{array}$ & Cause \\
\hline $\begin{array}{c}\text { A II } \\
(x: x, x: x)\end{array}$ & $\begin{array}{l}\text { Lyla McCann } \\
\text { Marhan }\end{array}$ & $\begin{array}{c}10: 10,13: 13 \\
\text { +dicentric } \\
\text { bridge } \\
48\end{array}$ & $\begin{array}{l}\text { so : } 14 \text { distribution from univalents } \\
\text { at } \mathrm{M} \text { I } \mathrm{b}+\mathrm{f} \text { inv. c.-o. (pl. } 2, \text { fig. } 3 \text { ) } \\
\text { Restitution of all four haploid nuclei }\end{array}$ \\
\hline \multirow[t]{6}{*}{$\begin{array}{l}\text { M III } \\
\left(x: 3^{x}\right)\end{array}$} & L. regale & $11: 37$ & $\begin{array}{l}\text { II: }: 3 \text { distribution from univalents } \\
\text { at } \mathrm{MI}\end{array}$ \\
\hline & Dalhansoni & $11: 37$ & $\begin{array}{l}\text { I : }: 13 \text { distribution from univalents } \\
\text { at } M \mathrm{I}\end{array}$ \\
\hline & Marhan & $10: 3^{8}$ & $\begin{array}{l}\text { 10: } 14 \text { distribution from univalents } \\
\text { at } M I\end{array}$ \\
\hline & Lyla McCann & $13: 35$ & $\begin{array}{l}\text { 13: } 1 \mathrm{y} \text { distribution from univalents } \\
\text { at } \mathrm{M} \mathrm{I}\end{array}$ \\
\hline & Lilian Cummings & $\begin{aligned} & 12: 34 \\
&+ \text { dicentric }\end{aligned}$ & $\begin{array}{l}\text { A I } 12: 12 \\
\text { A II } 12: 12,11: 13 . \text { Dicentric bridge } \\
\text { carried complete (pl. } 2 \text {, fig. } 6)\end{array}$ \\
\hline & Dalhansoni & $\begin{array}{l}23: 23+\text { active } \\
\text { micronuclei }\end{array}$ & $\begin{array}{l}\text { Univalent excluded as micronucleus } \\
\text { at A I or A II } \\
\text { Abnormal fusion at M III }\end{array}$ \\
\hline
\end{tabular}

found by Frankel et al (1940). As with the PMC's their reduced chiasma frequency results in univalents at MI. No misdivision of the centromere was observed but random movement of univalents at first or second division of meiosis results in irregular distribution of chromosomes (table 5) or the formation of micronuclei (table 6).

Inversion crossing-over results in bridges and fragments at first or second division. Bridges may break or be carried complete to one nucleus, or persist as interphase connections. When the bridge is carried complete to one nucleus (plate 2, fig. I) it forms a dicentric chromosome which can persist in subsequent mitoses. This results in unequal chromosome numbers in the embryo-sac nuclei (table 5). Bridges persist through interphase because no cell walls are formed. Restitution at the next division results in polyploid nuclei. 
Micronuclei can be formed by fragments from inversion crossingover as well as by lagging univalents. One unusual embryo-sac of Dalhansoni had two "near diploid" early anaphases. Each of these had 23 chromosomes and one had in addition the products of a delayed but active micronucleus (plate 2, fig. 8). The two " near diploid" nuclei, instead of one haploid and one triploid, result from abnormal differentiation. The micronucleus was probably formed by a lagging univalent. At M III the chromosomes in the micronucleus

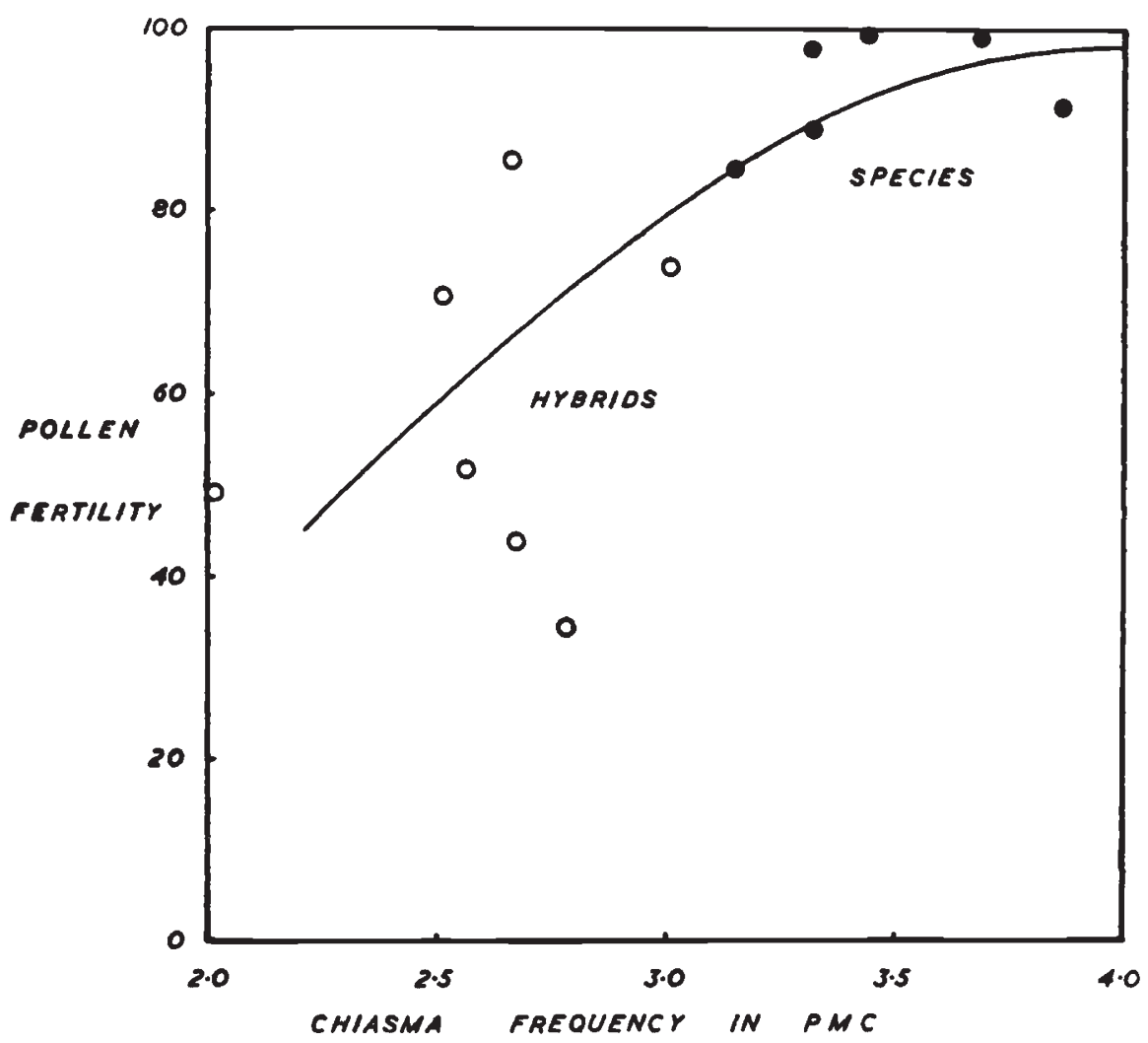

Fic. 3.-Relation between pollen fertility and chiasma frequency per potential bivalent in PMC of Lilium species and hybrids.

became active but delayed behind the main nucleus. The centromeres have separated while the chromosomes remain not fully spiralised.

Errors of synchronisation and differentiation.-The formation of the secondary four-nucleate embryo-sac with two haploid and two triploid nuclei depends on migration of one nucleus from the micropylar to the chalazal end and on synchronisation of mitoses in the three basal nuclei. The development of this stage is frequently abnormal in hybrids. Two tetraploid ; four diploid ; or four haploid plus two diploid nuclei being formed instead of two haploid and two triploid.

Failure of synchronisation occurs at the second division of meiosis in PMC of hybrids (table 3) but because of wall formation this has 
no consequence. A similar error in PMC of Tradescantia (Haque, I953) is accompanied by failure of wall formation at second division

TABLE 6

Abnormal embryo-sac development in Lilium hybrids. Individual figures for Edna Kean,

Lilian Cummings, Lyla McCann and Phyllis Cox have been totalled and shown as Stenographers

NORMAL ABNORMAL DALHANSONI MARHAN STENOGRAPHERS

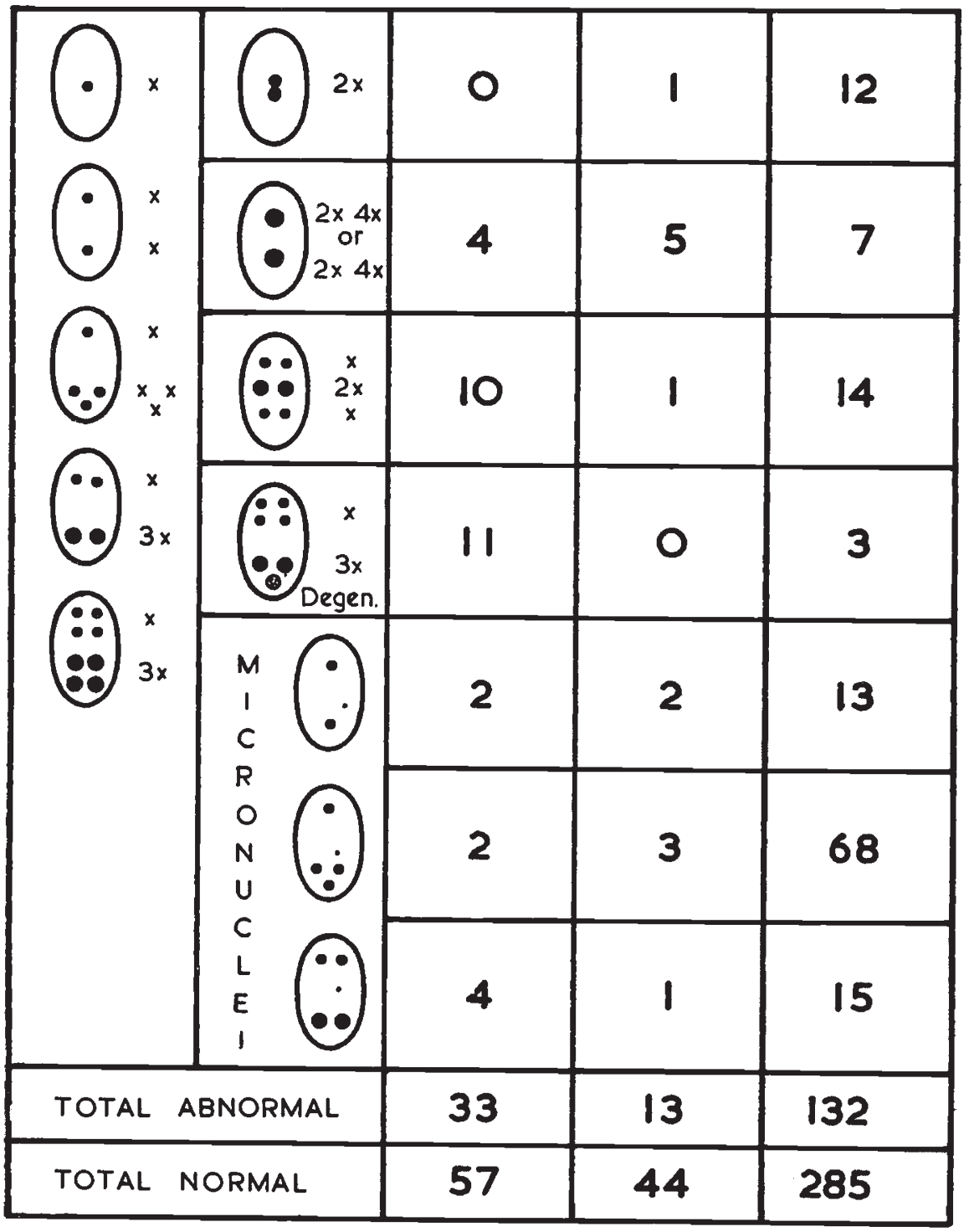

of meiosis. This results in binucleate pollen grains in some of which mitoses are not synchronised. A similar error in the embryo-sac would prevent the fusion of the three basal nuclei and produce abnormal chromosome distribution. 
Similar errors in chromosome distribution in the embryo-sac can arise from errors in cytoplasmic differentiation which controls the migration of the nucleus from the micropylar to the chalazal end of

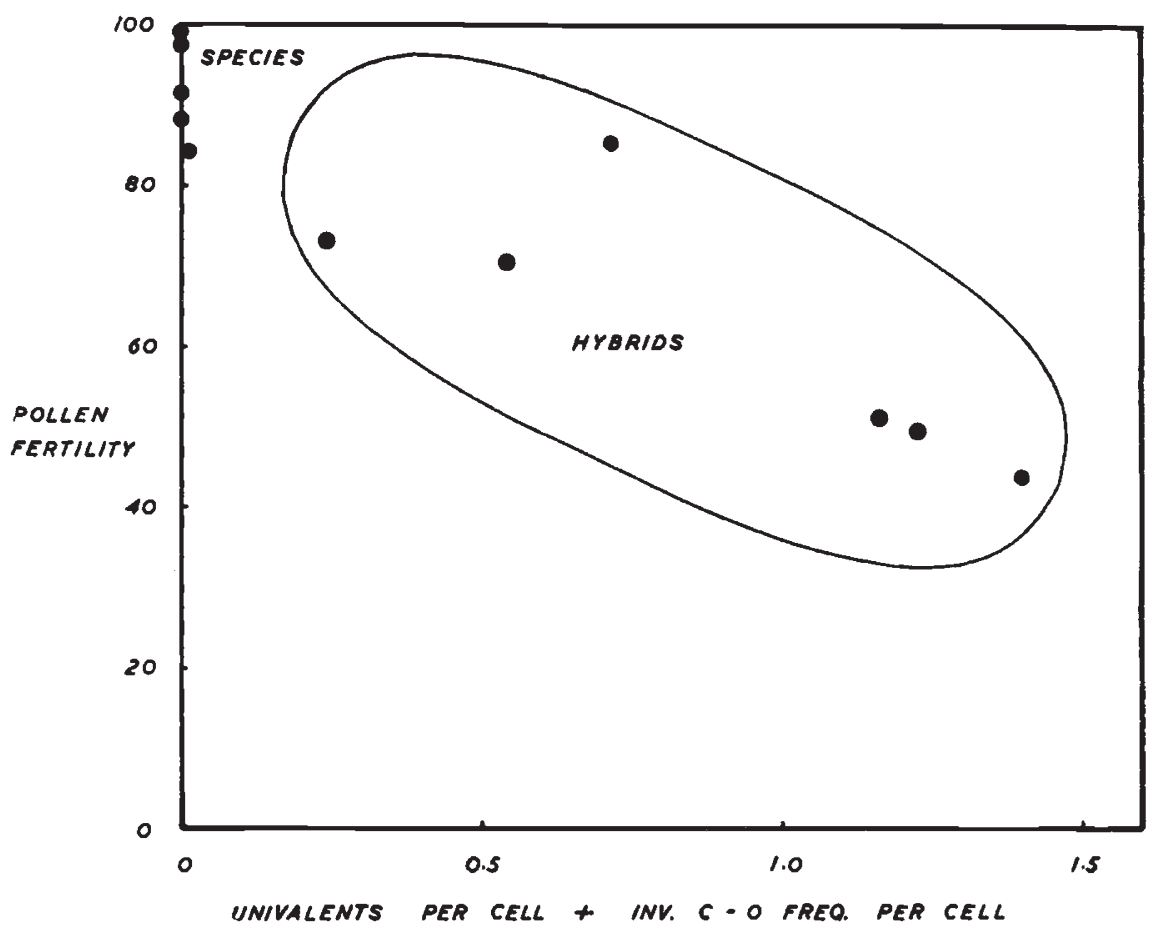

FIG. 4.-Graph showing relation of pollen fertility with the mean number of univalents per PMC and inversion crossing-over frequency per PMC in Lilium species and hybrids.

the embryo-sac. La Cour (1949) has shown the importance of cytoplasmic differentiation in the development of the pollen grain. The maternally determined cytoplasmic gradient in the embryo-sac can

$$
\begin{array}{llllll}
\text { M I } & \text { T I } & \text { T II } & \text { MIII } & \text { TIII } & \text { T IV }
\end{array}
$$
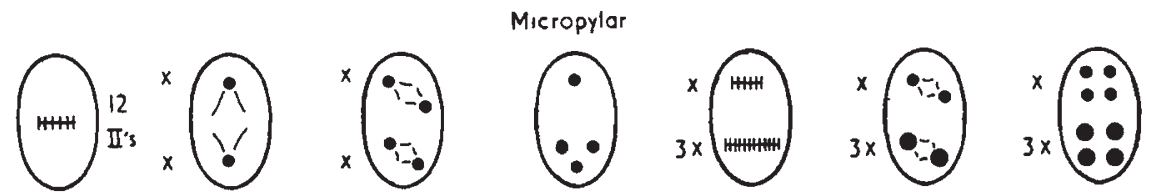

Chalazol

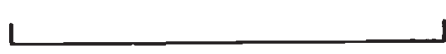

MEIOSIS

\section{MIGRATION}

MITOSIS

FIG. 5.-Normal embryo-sac development in Lilium $\mathrm{x}=\mathrm{I} 2$. II = bivalent.

presumably be influenced by the products of segregation, the haploid nuclei. In these hybrids the result of such interactions are observed as abnormalities in chromosome distribution. 
A further abnormality occurred at M IV in some of the species and hybrids where the basal triploid nucleus fails to divide, and sometimes degenerates. This results in seven or six nuclei in the mature embryo-sac but it probably has little effect on embryo-sac fertility for it merely reduces the number of the antipodal nuclei and does not affect the egg or polar nuclei. In calculating embryo-sac normality these have been regarded as normal.

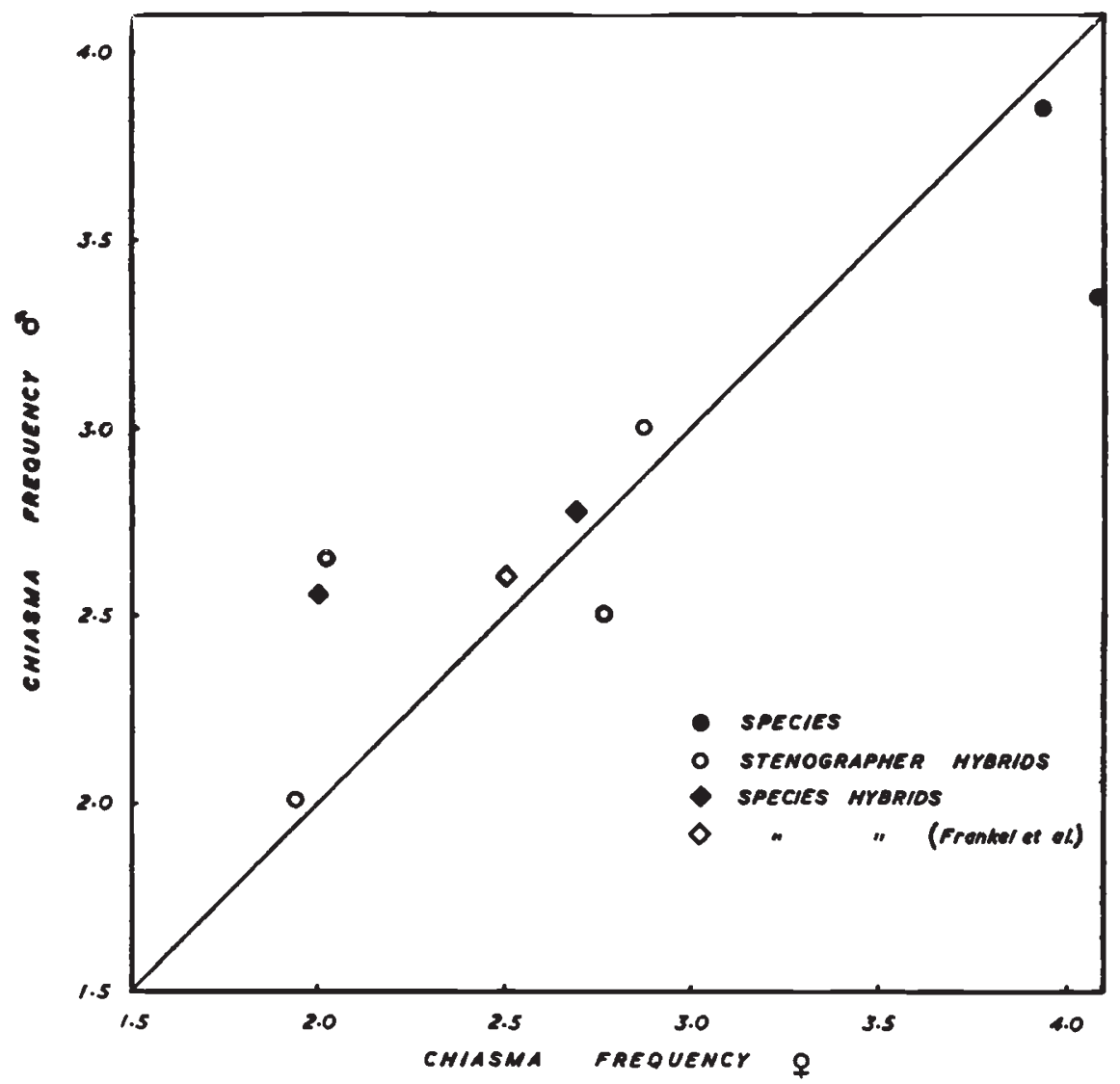

Fig. 6. - Chiasma frequency per potential bivalent of $\delta$ and $q$ cells plotted against one another. Deviations from equality not significant.

The level of embryo-sac sterility is similar to pollen sterility in these hybrids but it has a more direct effect on the fertility of the plant as measured by seed development.

\section{SEED DEVELOPING AFTER SELFING}

Based on seed development the species are either self-fertile or selfsterile (table 7). This behaviour suggests an incompatibility system such as pollen-style incompatibility but examination of pollen tube growth after selfing in fertile and sterile forms fails to support this suggestion. In $L$. regale, which is self-fertile, pollen tubes had reached 
the base of the style $(60 \mathrm{~mm}$.) three days after pollination and were at the ovule five days after pollination. In L. pardalinum, which is self sterile, pollen tubes were normal in appearance and had reached the base of the style five days after pollination. Fertilisation could not be definitely established and there were no ovules developing three weeks after pollination. Thus the incompatibility reaction is

TABLE 7

Pollen fertility, embryo-sac normality and seed development three weeks after self pollination, in Lilium species and hybrids

\begin{tabular}{|c|c|c|c|c|c|c|c|c|}
\hline & & $\begin{array}{c}\text { Pollen } \\
\text { fertility }\end{array}$ & $\begin{array}{c}\text { Embr } \\
\text { norn }\end{array}$ & $\begin{array}{l}\text { yo-sac } \\
\text { ality }\end{array}$ & Seec & developm & ent after self & \\
\hline & & $\begin{array}{l}\text { Per cent. } \\
\text { good } \\
\text { pollen }\end{array}$ & $\begin{array}{c}\text { No. of } \\
\text { embryo- } \\
\text { sacs }\end{array}$ & $\begin{array}{c}\text { Per cent. } \\
\text { normal }\end{array}$ & $\begin{array}{l}\text { No. of } \\
\text { ovaries }\end{array}$ & $\begin{array}{l}\text { Ovary } \\
\text { swelling } \\
\text { ovule } \\
\text { devel. }\end{array}$ & $\begin{array}{l}\text { No. ovules } \\
\text { examined }\end{array}$ & $\begin{array}{c}\text { Per cent. } \\
\text { with devel. } \\
\text { endo- } \\
\text { sperms }\end{array}$ \\
\hline SPECIES-Self sterile & & & & & & & & \\
\hline L. candidum & & $84: 5$ & 14 & 100 & 2 & + & $3^{12}$ & $o$ \\
\hline $\begin{array}{l}\text { L. Davara } \\
\text { L. Hansonii }\end{array}$ & & $\begin{array}{l}97 \cdot 4 \\
88 \cdot \pi\end{array}$ & $\because 20$ & $\ddot{100}$ & $\begin{array}{l}3 \\
3\end{array}$ & $\overline{-}$ & $\cdots$ & $\cdots$ \\
\hline L. Henryi & & $98 \cdot 9$ & $\ldots$ & $\ldots$ & 2 & - & $\ldots$ & $\ldots$ \\
\hline L. pardalinum & & 983 & II 4 & 100 & 12 & - & $\ldots$ & $\ldots$ \\
\hline SPECIES-Self fertile & & & & & & & & \\
\hline $\begin{array}{l}\text { L. regale } \\
\text { L. Szovitsianum }\end{array}$ & & $\begin{array}{l}91 \cdot 3 \\
96 \cdot 7\end{array}$ & $\begin{array}{l}: 52 \\
\ldots\end{array}$ & $\begin{array}{c}99.4 \\
\ldots\end{array}$ & $\begin{array}{r}12 \\
2\end{array}$ & + & $\begin{array}{l}115 \\
468\end{array}$ & $\begin{array}{c}95 \cdot 6^{*} \\
3^{\circ} 0\end{array}$ \\
\hline$F_{1}$ 's & & & & & & & & \\
\hline $\begin{array}{l}\text { Marhan } \\
\text { Dalhansoni }\end{array}$ & & $5^{I} \cdot 5$ & 62 & $72 \cdot 6$ & 3 & + & 150 & $147^{*} *$ \\
\hline Dalnansont & & $34: 5$ & 102 & $74: 5$ & 4 & + & 624 & $\boldsymbol{I} \cdot \boldsymbol{I}^{*}$ \\
\hline MULTIPLE HYBRIDS & & & & & & & & \\
\hline Lyla McCann. & & $49 \cdot 3$ & 44 & $38 \cdot 6$ & 5 & + & 684 & $x: 5^{*}$ \\
\hline Lilian Cummings & & $70 \cdot 6$ & 137 & $68 \cdot 6$ & 5 & $\stackrel{+}{+}$ & 1050 & $5 \cdot 4$ \\
\hline $\begin{array}{l}\text { Edna Kean } \\
\text { Phyllis Cox }\end{array}$ & & $\begin{array}{l}85 \cdot 5 \\
73 \cdot 1\end{array}$ & $\begin{array}{r}210 \\
65\end{array}$ & $\begin{array}{l}73 \cdot 3 \\
70 \cdot 8\end{array}$ & $\begin{array}{l}3 \\
6\end{array}$ & $\begin{array}{c}\text { sight } \\
+\end{array}$ & $\begin{array}{r}762 \\
1482\end{array}$ & $4^{0} \cdot 6^{*}$ \\
\hline Coronation & & $43 \cdot 8$ & $\ldots$ & $\ldots$ & 5 & slight & 1080 & $o$ \\
\hline
\end{tabular}

Note.-Pollen fertility is based on examination of 800 to 1200 pollen grains for each species and hybrid.

* Including some endosperms with spontaneous chromosome breakage.

determined very late and it may occur after fertilisation as has been suggested for Hemerocallis (Stout and Chandler, I933), Gasteria (Sears, 1937) and Theobroma (Knight and Rogers, I953).

Spontaneous chromosome breakage, resulting in degeneration of the endosperm and abortion of the embryo has already been reported in Lilium. This occurs frequently in hybrids and occasionally in the self fertile species, $L$. regale, and it may constitute the mechanism of incompatibility in the self sterile species. The swelling of the ovaries of $L$. candidum and $L$. Szovitsianum suggests a response either to pollination or to fertilisation and supports the view that seed development may fail after fertilisation. But it was not possible to establish that fertilisation had occurred. 
In the hybrids, however, every ovary swelled and three weeks after pollination there had been considerable failure of ovules after fertilisation.

Although the full explanation of the seed failure in the species cannot be given it is clear that, in the hybrids, the failure of seed development after fertilisation is more important in determining fertility than either the pollen or the embryo-sac fertility.

\section{SUMMARY}

I. Fertility in Lilium hybrids, measured by seed development after selfing, is reduced by pollen sterility, embryo-sac sterility and failure after fertilisation.

2. Some are structural hybrids with reduced chiasma frequency, univalents at $\mathrm{MI}$, and crossing-over in inverted segments.

3. Segregation is responsible for differences in nuclei. These have different mitotic rates and cause errors in cytoplasmic differentiation in the embryo-sac.

4. Spontaneous chromosome breakage in the endosperm of hybrids is followed by degeneration of the fertilised ovule.

5. Sterility in these hybrids is thus seen to arise from errors at three stages :

(i) Meiosis-Reduced chiasma frequency and inversion crossingover.

(ii) Mitosis-Errors of differentiation and synchronisation.

(iii) After fertilisation-Endosperm failure.

6. In self-sterile species pollen tube growth is normal and the sterility mechanism seems to operate at or after fertilisation.

\section{REFERENCES}

BROCK, R. D. 1954. Spontaneous chromosome breakage in Lilium endosperm. Ann. Bot., 18, 7-1 4.

Darlington, C. D. 1937. Recent Advances in Cytology. 2nd ed. London.

FRANKEL, O. H., DARLINGTON, C. D., AND LA COUR, L. F. 1940. Causal sequence of meiosis. 7. Genet., $4 I, 9-64$.

HAQUE, A. 1953. Non-synchronised mitosis in a common cytoplasm. Heredity, $7,429-432$.

KNIGHT, R., AND ROGERS, H. H. 1953. Sterility in Theobroma cacao. Nature, 171,164 . LA COUR, L. F. 1949. Nuclear differentiation in the pollen grain. Heredity, 3, 319-337.

RICHARDSON, M. M. 1936. Structural hybridity in Lilium martagon album $\times$ L. hansoni. 7. Genet., 32, $4^{11-450 .}$

SEARS, E. R. 1937. Self sterility in plants. Genetics, 22, 130-181.

stout, A. B., AND CHANDLER, c. 1933. Pollen tube behaviour in Hemerocallis with special reference to incompatibilities. Bull. Torrey Bot. Club, 6o, 397-417. WOODCOCK, H. B. D., AND STEARN, W. T. 1950. Lilies of the World. London: Country Life Ltd. 


\section{Plate $I$}

Normal embryo-sac development in Lilium

Fixation Carnoy fluid $(6: 3: 1)$. Stained Feulgen reagent. Dissected end squashed in 45 per cent. acetic acid.

Fig. 1.-Pachytene.

FIG. 2.-First metaphase of meiosis (MI) I 2 bivalents.

FIG. 3.-Second metaphase of meiosis (M II). Chromosomes $12:$ I2.

Fig. 4.-Second anaphase of meiosis (A II). Chromosomes $12: 12: 12: 12$.

FIG. 5.-Interphase after T II, migration of one nucleus from micropylar to chalazal end of embryo-sac.

FIG. 6.-Anaphase (A III) producing secondary four nucleate embryo-sac. Chromosome distribution $12: 12: 36: 36$.

All figures : $\times 380$. 

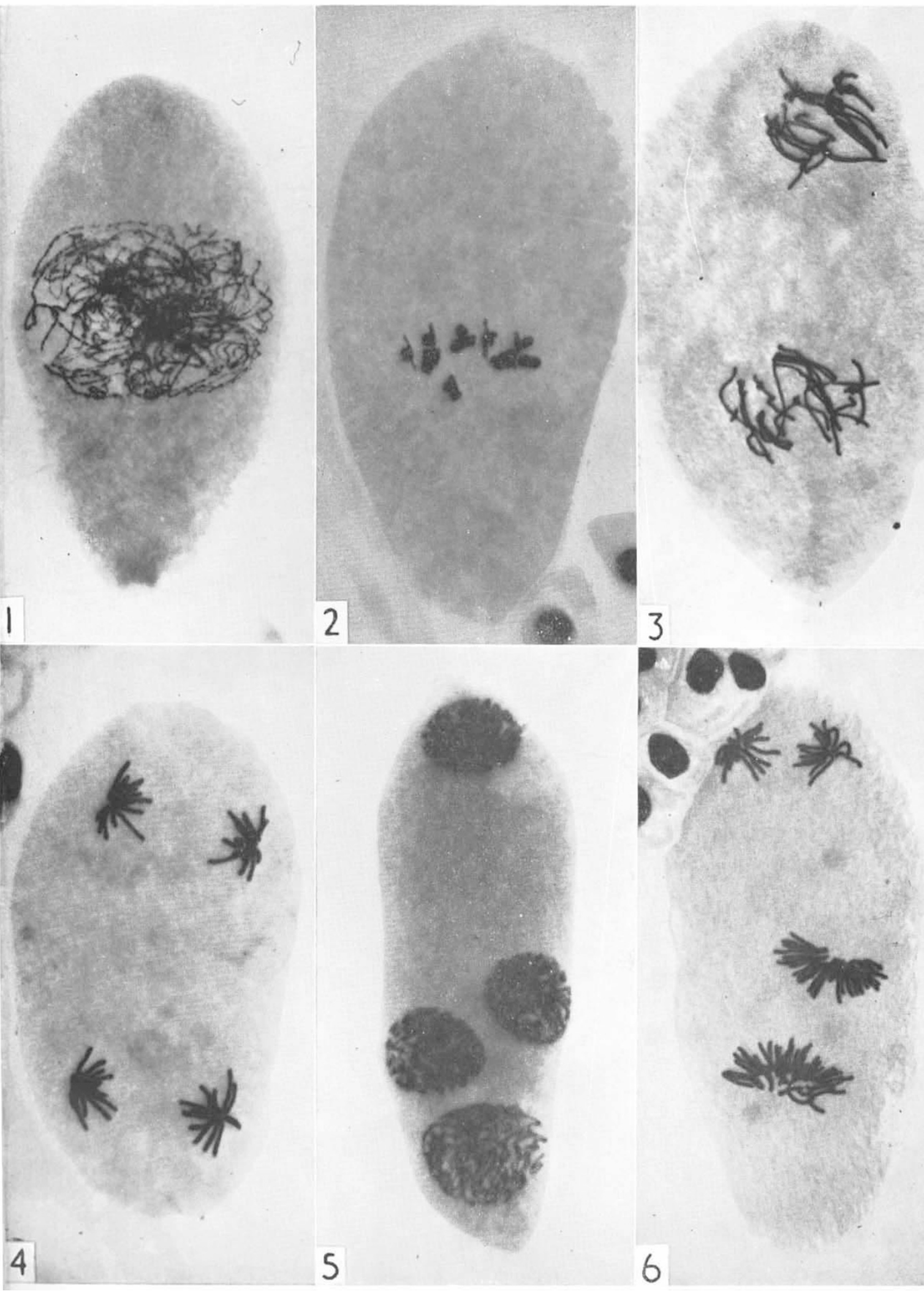
Plate 2

Abnormalities in embryo-sac development in Lilium hybrids. Technique-as for plate I

FIG. I.--Inversion crossing-over bridge and fragment at A I. Bridge being carried complete to one nucleus. Chromosome distribution I I : I I + dicentric. $\times$

Fig. 2.- Interphase bridge after first division of meiosis. Restitution at next division will result in diploid nuclei.

Fig. 3.--Inversion crossing-over bridge and fragment at A II. Chromosome distribution I $3:$ I $_{3}+\mathrm{C}_{2}$ bridge, $10:$ io.

FIG. 4.-Fusion of spindles of chalazal nuclei at M III. Also a micronucleus from abnormality at $\mathrm{M} \mathrm{I}$ and an acentric fragment from abnormality at M II. Chromosome distribution probably I $2: 36$.

FIG. 5.-Failure of spindle fusion at $M$ III resulting in $x, x, 2 x, 2 x, x, x$ instead of $x, x, 3 x, 3^{x}$.

FIG. 6.-M III showing dicentric chromosome in $3 x$ nucleus. This results from inversion crossing-over bridge at A II being carried complete. Chromosome distribution 1 $2: 34$ +dicentric.

FIG. 7.-T II with micronucleus.

FIG. 8.-One of the two very early anaphases at A III showing products of delayed but active micronucleus. Chromosome distribution $23: 23+$ active micronucleus.

Figs. $1-7: \times 380$. Fig. $8: \times 145^{\circ}$. 
